\title{
Transformational Leadership with Moon Character: Empirical Evidence at STIEM Bongaya Campus
}

\author{
Abdi Akbar \\ Fakultas Ekonomi Universitas Negeri Makassar (UNM) \\ Email address: \\ abdiakbar@msn.com
}

\begin{abstract}
The leadership style at STIEM Bongaya is transformational leadership with a moon character not found on other campuses in Makassar City. We examine the role of involvement and the proactive role of transformational leadership relationships with employee performance. The reason for choosing the object is because the characteristics of ownership are family owned and are directed by second-generation family members, so it is interesting to study. This study used a sample of 83 employees to obtain accurate information in analyzing data by using WarpPLS 5.0. We find the transformational leadership of the moon character can improve employee performance. Because the leaders always emit the moonlight form of new enthusiasm, harmonization, comfort, and coolness, the employee engagement behavior becomes high. It has been rooted among employees that work orientation is noble. Involvement will be meaningful if there is an intelligent proactive role by the employee and the employee's performance becomes quality.
\end{abstract}

Keywords: Moon leadership, involvement, proactivity, employee performance.

\begin{abstract}
Abstrak: Gaya kepemimpinan di STIEM Bongaya adalah kepemimpinan transformasional berkarakter rembulan yang tidak ditemukan pada kampus lain di Kota Makassar. Kami menginvestigasi hubungan kepemimpinan transformasional dengan kinerja karyawan melalui peran keterlibatan dan peran proaktif. Alasan pemilihan objek tersebut karena karakteristikk kepemilikan adalah kepemilikan keluarga dan dinahkodai oleh anggota keluarga generasi kedua, sehingga menarik diteliti. Seluruh karyawan ditetapkan sebagai sampel (sampel jenu) yakni sebanyak 83 responden dan untuk mendapatkan informasi akurat maka analisis data menggunakan WarpPLS 5.0. Kami menemukan bahwa semakin baik kepemimpinan transformasional berkarakter rembulan semakin tinggi kinerja karyawan. Karena pimpinan selalu memancarkan sinar rembulannya berupa semangat baru, harmonisasi, kenyaman dan kesejukan maka perilaku keterlibatan karyawan menjadi tinggi. Telah mengakar disanubari karyawan bahwa orientasi kerja adalah mulia. Keterlibatan akan bermakna jika ada peran proaktif yang cerdas oleh karyawan dan kinerja karyawan menjadi berkualitas.
\end{abstract}

Kata kunci: Kepemimpinan rembulan, keterlibatan, proaktif, kinerja karyawan. 


\section{INTRODUCTION}

Transformational leadership is the leader who protects the institution and employees that raising awareness for the followers or employees in changing the mentality and motivating them to do better than the organization expected (Buil et al., 2018). Long before that, (Mohamad, 1986) conducted a review of the theory of conventional transformational leadership by Bass (1985) based on individual considerations, charismatic values, inspirational motivation, and intellectual stimulation. It is true, psychologically, these values serve as encouragement for followers. But we have not found a match between the value of love (heart) or coolness. We believe that transformational leadership does not highlight the quid-pro-quo behavior which characterizes transactional leadership (Antonakis and House, 2014). (Kara et al., 2013) reinforced that transformational leadership is more effective than transactional leadership styles.

(Afsar and Umrani, 2019); (Mahmood et al., 2019) stated that transformational leadership with a heart with a calm atmosphere. A leader with a heart will create a calm atmosphere as a leader with moon character. It means that a leader with the moon character will strengthen his followers psychologically, such as cooperation, proactivity, and involvement (Gumusluoglu and Ilsev, 2009) and personal performance. Therefore, transformational leadership that has a moon character becomes interesting for research.

Transformational leadership with a moon character encourages calm social cohesion for employees. Moreover, employees feel comfortable at work (Sharma and Pearsall, 2016) and tend to be more productive in employee performance. A leader with a moon character always provides coolness to employees, especially employees who experience work stress conditions due to the large volume of work. The study of (Yao et al., 2014) argued that transformational leadership was related to job stress and negative employee behavior. Even employees tend to show innovative behavior and show positive attitudes towards job satisfaction (Al-edenat, 2018).

This study contributes to complementing the measurement of conventional transformational leadership theory by Bass (1985) by offering a new concept in transformational leadership that believes transformational leadership has moon characteristics. We believe that transformational leadership conventional theory has not yet found a match between values based on the nature of the universe; Ilmu Hasta Brata. The strength of Hasta Brata's leadership knowledge is the element of nature, one of which is the leader as the moon. Leadership as the moon can illuminate the darkness of the night, and the current leader must be able to provide enthusiasm, support, and motivation during joy and sorrow, whatever and whatever the situation and condition the leader must be present and become the social glue so that the inner atmosphere of employees or organizational members is in well maintained. Transformational leadership with a moon character will be meaningful if it can encourage employees to be significantly involved in the organization so that employee performance is good and quality (Buil et al., 2019). (Ghadi et al., 2013); (Li et al., 2018); (Tims et al., 2011) stated that the better transformational leadership, the higher the employee involvement in the organization. Employee engagement becomes stronger if employees are more proactive so that it impacts employee performance (Li et al., 2012; (Wang et al., 2017; Yang et al., 2017). Therefore, employee proactive variables become a moderating variable between transformational leadership and employee engagement. 
The article consists of theoretical study, methodology, research result, discussion, and conclusion.

\section{THEORETICAL REVIEW}

The assumption of transformational leadership theory by (Bass, 1985) is limited to targeting psychological aspects. The new assumption of transformational leadership theory by (Bass, 1985) is limited to targeting psychological aspects that give change and encourage employees to innovate so that they impress their employees. (Afsar et al., 2019) stated that transformational leadership positively influences employee innovation behavior, includes idea creation and idea implementation. Besides, the employees give psychological support that becomes a strength for a leader with a moon character. Transformational leadership with a moonlike character's will build calmness or comfort for employees. Leaders with the moon character will get social support so that employees are more flexible in making adjustments to the organizational climate so that employee performance is good (Lee et al., 2013). (Mullen et al.,2017), (Thomas Ng, 2017), (Tse and Chiu, 2014) reported that the better transformational leadership, the better employee performance. Therefore, the first hypothesis is:

H1: Transformational leadership style with moon character is related to employee performance.

Transformational leadership with a moon character is increasingly trusted by employees, and their involvement in the organization will be higher (Jena et al., 2017). Thus, the employee's performance is getting better, and quality. Employee involvement can be interpreted as the emotional commitment that employees have in doing work. Employees will be happy, cheerful, and happy to do their job and not consider it a burden (Sumail, 2019). (Buil et al., 2018) study; (Salau et al., 2018) stated that the better transformational leadership, the higher the employee involvement. Therefore, the second hypothesis is:

H2: Transformational leadership with a moon character affects employee engagement.

Following transformational leadership factors that affect employee engagement attitudes, it is also determined by individual proactivity. An individual's proactive attitude is an action based on the beliefs they have through evaluative things, it can be objects, people, or events. It may be that a proactive attitude is born because of awareness, belief, and a calm environment so that a person tends to be more involved in work. (Bateman and Crant, 1993) an effort work environment encourages someone to be proactive. (Presbytero, 2015); (Setti et al., 2010) found that driven individuals can vitalize employee engagement so that employee performance is good and quality. Therefore, the third hypothesis is:

H3: Transformational leadership with a moon character affects employee engagement with proactive moderation of employees. 
Employee involvement in the organization is caused by emotional factors (Ouweneel et al., 2012; Yoo and Jeong, 2017; Yulita et al., 2017). (Paek et al., 2015) stated that employee involvement is influenced by psychological factors, job satisfaction, and organizational commitment. It means that the higher the psychological (emotional) factors, job satisfaction, and organizational commitment, the higher the employee's involvement in doing the job so that the employee's performance is getting better and of quality. (Anitha, 2014), (Gupta, 2019), (Hanaysha, 2016) reports that the higher the involvement, the better the employee's performance. Thus, the fourth hypothesis is:

H4: Employee involvement affects employee performance.

In addition to psychological (emotional) factors, employee engagement is determined by transformational leadership. One of the hallmarks of employee engagement is showing creative behavior. This creativity arises because of psychological factors where the organization guarantees a good-work climate (Li et al., 2015). Therefore, transformational leadership that has a moon character will encourage employees to be involved in the organization. Of course, employees will interpret work as not a burden but worship to do work so that employee performance will be good and of quality. (Ghadi et al., 2013) tried to investigate the direct relationship between transformational leadership and job involvement mediated by employees' perceptions of the meaning in work is a positive relationship. Therefore, the researchers (Buil et al., 2018), (Ding et al., 2017), (Monje et al., 2019) revealed that transformational leadership is related to employee engagement. High employee involvement will drive performance (Anitha, 2014; Gupta, 2019; Hanaysha, 2016). Therefore, the fifth research hypothesis is:

H5: Moon's transformational leadership affects employee performance mediated by employee involvement.

\section{METHODS}

The researcher chose the research object at the STIEM Bongaya Campus because the characteristics of ownership belonged to the family and the campus leader of the second generation family members. It is interesting to research. The sampling technique used the Jenu sample that assigned all employees. The sample research is 83 respondents with has the indicator for each variable. The indicator is the combination of the research object with the previous research.

The transformational leadership variable uses indicators (1) with moon or coolness characteristics, (2) inspirational motivation for employees, and (3) encouraging employees to innovate (Afsar et al., 2014). Employee involvement variable indicators are (1) commitment, (2) dedication, and (3) absorption (full involvement in work) (Buil et al., 2018). Employee proactive variable indicators are (1) looking for better ways to work and (2) superior in identifying opportunities (Buil et al., 2018). Employee performance variable indicators are (1) performing urgent tasks, (2) meeting job requirements, (3) on time, and (4) never neglecting job aspects (Groen et al., 2017).

Because this research is perception research so that the data collection uses a Likert scale with the questionnaires declared valid (r>0.30) and reliable (> alpha 0.60) (Solimun et al. 
2017). In finding out the errors in questionnaires, the research edited the data collected. The goal is to produce accurate data. Finally, data analysis was carried out using WarpPLS 5.0 software and interpreting the results of data analysis.

\section{RESULTS}

It seems that there is a gender equality role that works at the Bongaya STIEM Campus is evident that the number is almost the same between male is 55 percent, and female is 45 percent. It is believed that gender equality can increase the employee mindset to innovate (Rönnblom \& Keisu, 2013; Rowe, 2018). The role of gender equality is in the innovation of a campus. The study found that the average productive age of employees between 20-35 years was 55\% and between the ages of 36-55 years was $40 \%$. Moreover, the dominance of employee education level is $97 \%$ (see Table 1).

Table 1. Characteristics of Respondents

\begin{tabular}{|c|c|c|}
\hline Characteristics & \multicolumn{2}{|c|}{ Employees } \\
\hline \multirow[t]{2}{*}{ Gender } & Male & $55 \%$ \\
\hline & Female & $45 \%$ \\
\hline \multirow[t]{3}{*}{ Age } & $20-35$ & $55 \%$ \\
\hline & $36-55$ & $40 \%$ \\
\hline & $>55$ & $5 \%$ \\
\hline \multirow[t]{2}{*}{ Education } & $\mathrm{S} 1$ & $97 \%$ \\
\hline & $\mathrm{S} 2$ & $3 \%$ \\
\hline
\end{tabular}

Source: Research results 2020

After testing the research instrument, testing the validity and reliability, then re-checking the indicators use to meet the validity and reliability standards.

Table 2. Combined Loadings and Cross Loadings

\begin{tabular}{lccccc}
\hline \multicolumn{1}{c}{ Indicator } & $\begin{array}{c}\text { Transformationa } \\
\text { l Leadership } \\
\text { (TL) }\end{array}$ & $\begin{array}{c}\text { Employee } \\
\text { Engagement } \\
\text { (EE) }\end{array}$ & $\begin{array}{c}\text { Employee } \\
\text { performance } \\
\text { (EP) }\end{array}$ & $\begin{array}{c}\text { Proactive } \\
\text { employees } \\
\text { (PE) }\end{array}$ & $\begin{array}{c}\text { Validity } \\
\text { (P-value) }\end{array}$ \\
\hline Calmness (X1.1) & $\mathbf{0 . 8 5 8}$ & 0.049 & -0.216 & 0.381 & 0.001 \\
New spirit (X1.2) & $\mathbf{0 . 5 4 0}$ & -0.240 & 0.284 & 0.062 & 0.001 \\
Harmoniousi (X1.3) & $\mathbf{0 . 8 2 6}$ & 0.104 & 0.029 & -0.406 & 0.001 \\
Commitment (Y1.1) & 0.156 & $\mathbf{0 . 6 8 8}$ & 0.291 & -0.205 & 0.001 \\
Dedication (Y1.2) & 0.069 & $\mathbf{0 . 7 6 3}$ & -0.095 & -0.099 & 0.001 \\
Absorption (Y1.3) & -0.244 & $\mathbf{0 . 6 5 7}$ & -0.194 & 0.329 & 0.001 \\
$\begin{array}{l}\text { Doing an urgent task } \\
\text { (Y2.1) }\end{array}$ & -0.171 & 0.198 & $\mathbf{0 . 5 7 0}$ & 0.368 & 0.001 \\
Fulfill the requirements & -0.109 & 0.076 & $\mathbf{0 . 8 5 4}$ & -0.013 & 0.001 \\
(Y2.2) & 0.371 & -0.195 & $\mathbf{0 . 8 2 3}$ & -0.157 & 0.001 \\
On-time Y2.3 & & & & & 0.001 \\
Never neglect the work & -0.209 & -0.031 & $\mathbf{0 . 5 5 2}$ & -0.126 & 0.001 \\
aspect (Y2.4) & & & & & 0.001 \\
Looking for a better & -0.001 & 0.309 & -0.256 & $\mathbf{0 . 7 8 3}$ &
\end{tabular}


Excels at identifying opportunities M2

Note: The level of significance p-value $\alpha 0.05$

The results of the cross-check all indicators were declared valid (see Table 2). The factor load was $>0.30$ or $\mathrm{p}<0.001$. The result of the alpha coefficient test is above the value of 0.70 so that all indicators are declared reliable (Solimun et al. 2017).

Table 3. Reliability test

\begin{tabular}{ccccc}
\hline Indicator & $\begin{array}{c}\text { Transformationa } \\
\text { 1 Leadership } \\
(\text { TL) }\end{array}$ & $\begin{array}{c}\text { Variable } \\
\text { Enployee } \\
\text { Engagement } \\
\text { (WE) }\end{array}$ & $\begin{array}{c}\text { Employee } \\
\text { Performance } \\
\text { (EP) }\end{array}$ & $\begin{array}{c}\text { Proactive } \\
\text { Employee } \\
\text { (PE) }\end{array}$ \\
\cline { 2 - 6 } Alpha Coefficient & 0.777 & 0.784 & 0.796 & 0.770 \\
\hline Description: The indicators are reliable & & & &
\end{tabular}

Table 4 stated that the Average path coefficient (APC) is 0.461 . The average path coefficient is close to $50 \%$, so it can be stated that the explanatory (independent) variable can respond to the dependent variable. Average R-squared $(A R S)=0.465$. It showed that the average determinant correlation is below $50 \%$ so that between variables is stated to correlate. Then, the value of 0.451 showed the level of the Average adjusted R-squared (AARS). This value indicated that the correlation of several independent variables is below 50\%. The three indicators of the goodness of this model have a $\mathrm{p}$-value of $\mathrm{P}<0.001$. The data is declared good, and the model can be stated to be good because it is almost close to $50 \%$. Therefore, the data can be explained by models (Sumail and Abdullah, 2019).

Table 4. Model Goodness

\begin{tabular}{lcc}
\hline \multicolumn{1}{c}{ Indicator of Goodness Model } & Result & Information \\
\hline Criteria $(\mathrm{p}<0,05)$ & & \\
APC & $0.461^{* *}$ & Good \\
ARS & $0.465^{* *}$ & Good \\
AARS & $0.451^{* *}$ & Good \\
\hline
\end{tabular}

Note: $* *=$ significant

Reference to indicator formulation based on theory, previous research, logic, and the object of reality. Factor load showed the most important and the least important indicators in reflecting each variable. Furthermore, the mean value of indicators and variables is also juxtaposed. The indicator showed the actual conditions and the information obtained accurately. 
Table 5. The value of the factor weights and the mean of transformational leadership variables

\begin{tabular}{clccc}
\hline \multirow{2}{*}{ Variable } & \multicolumn{1}{c}{ Indicator } & Factor & \multicolumn{2}{c}{ Mean } \\
\cline { 4 - 5 } & & Loading & Indicator & Variable \\
\hline Transformational & Calmness (TL.1) & $\mathbf{0 . 8 5 8}$ & 3.9 & \multirow{2}{*}{ Leadership Moon } \\
Character (TL) & New Spirit (TL.2) & 0.540 & 4.0 & 3.9 \\
\hline
\end{tabular}

Note: The thickened numeric mark is the most important indicator

The mean value obtained by the transformational leadership variable is 3.9 is good, so the three indicators must be maintained. The strongest indicator in reflecting transformational leadership at the STIEM Bongaya Campus is an indicator of encouraging leaders with a moon or cool characteristics of 0.858. It means that the leader always presents a calm and comfortable atmosphere so that the working atmosphere between employees is more harmonious and employee performance will be better.

Table 6. The value of the factor weights and the mean of employee involvement variables

\begin{tabular}{clccc}
\hline \multirow{2}{*}{ Variable } & \multicolumn{1}{c}{ Indicator } & Factor & \multicolumn{2}{c}{ Mean } \\
\cline { 4 - 5 } & & Loading & Indicator & Variable \\
\hline Employee & Commitment (WE.1) & 0.688 & 4.1 & \\
Engagement & Dedication (WE.2) & $\mathbf{0 . 7 6 3}$ & 4.0 & \multirow{2}{*}{3.9} \\
(WE) & Absorption (full involvement in & 0.657 & 3.8 & \\
\hline
\end{tabular}

Note: The thickened numeric mark is the most important indicator

The average value obtained by the employee involvement variable of 3.9 is good, so the three indicators must be maintained. The strongest indicator in reflecting employee involvement at STIEM Bongaya Campus is a dedication indicator of 0.763. It means the high dedication of employees in implementing the employee engagement behavior role is a work-ethic form that needs to be maintained or managed by employees. High involvement will encourage employee performance to be good.

Table 7. The value of the factor weights and the average employee performance variables

\begin{tabular}{clccc}
\hline \multirow{2}{*}{ Variable } & \multicolumn{1}{c}{ Indicator } & Factor & \multicolumn{2}{c}{ Means } \\
\cline { 3 - 5 } & & Loading & Indicator & Variable \\
\hline \multirow{2}{*}{ Employee } & Performing an urgent task (EP.1) & 0.570 & 4.1 & \\
Performance & Meet the job requirements (EP.2) & $\mathbf{0 . 8 5 4}$ & 4.0 & 4.0 \\
(EP) & On-time (EP.3) & 0.823 & 4.0 & \\
& Never neglecting the work aspect (EP.4) & 0.552 & 4.0 & \\
\hline
\end{tabular}

Description: The bolded numeric mark is the most important indicator 
The average value obtained by the employee performance variable is 4.0 is good, so the three indicators must be maintained. The strongest indicator in reflecting the performance of employees at the STIEM Bongaya Campus is the indicator that meets the job requirements of 0.854 . It means that the employee's work meets the requirements to be of high quality. Employees perceive that work is important to themselves, outside the organization, so they are involved a great-deal in working and producing a good performance.

Table 8. Value of factor weight and mean of proactive employee variables

\begin{tabular}{|c|c|c|c|c|}
\hline \multirow{2}{*}{ Variable } & \multirow{2}{*}{ Indicator } & \multirow{2}{*}{$\begin{array}{l}\text { Factor } \\
\text { Loading }\end{array}$} & \multicolumn{2}{|c|}{ Mean } \\
\hline & & & Indicator & Variable \\
\hline \multirow{2}{*}{$\begin{array}{l}\text { Proactive } \\
\text { Employees } \\
\text { (PE) }\end{array}$} & $\begin{array}{l}\text { Looking for a better way of } \\
\text { working (PE.1) }\end{array}$ & 0.783 & 4.0 & \multirow{2}{*}{4.0} \\
\hline & $\begin{array}{l}\text { Excels at identifying opportunities } \\
\text { (PE.2) }\end{array}$ & 0.781 & 4.0 & \\
\hline
\end{tabular}

Description: The bolded numeric mark is the most important indicator

The average value obtained by the proactive employee variable of 4.0 is good, maintaining the three indicators. The strongest indicator in reflecting the proactivity of employees at the STIEM Bongaya Campus is an indicator of looking for a better way of working for 0.783 . Employees who are proactive at work. This kind of proactive employee attitude will increase employee involvement in doing work.

Table 9. Result of path coefficients

\begin{tabular}{|c|c|c|c|}
\hline Hypothesis & Coefficient & Significance & Information \\
\hline \multicolumn{4}{|l|}{ Direct relationship } \\
\hline $\begin{array}{l}\text { Transformational Leadership } \rightarrow \text { Employee } \\
\text { Performance }\end{array}$ & $0.440 * * *$ & 0.001 & $\begin{array}{l}\text { highly } \\
\text { significant }\end{array}$ \\
\hline $\begin{array}{l}\text { Transformational Leadership } \rightarrow \text { Employee } \\
\text { Engagement }\end{array}$ & $0.513 * * *$ & 0.001 & $\begin{array}{l}\text { highly } \\
\text { significant }\end{array}$ \\
\hline $\begin{array}{l}\text { Employee Engagement } \rightarrow \text { Employee } \\
\text { Performance }\end{array}$ & $0.479 * * *$ & 0.001 & $\begin{array}{l}\text { highly } \\
\text { significant }\end{array}$ \\
\hline \multicolumn{4}{|l|}{ Mediation relationship } \\
\hline $\begin{array}{l}\text { Transformational Leadership } \rightarrow \text { Employee } \\
\text { Engagement } \rightarrow \text { Employee Performance }\end{array}$ & $0.246 * * *$ & 0.001 & $\begin{array}{l}\text { Partial } \\
\text { mediation }\end{array}$ \\
\hline Moderation Relation & & & \\
\hline $\begin{array}{l}\text { Transformation Leadership* Employee } \\
\text { Engagement } \rightarrow \text { Employee Performance }\end{array}$ & $-0.410 * * *$ & 0.001 & $\begin{array}{l}\text { Quasi } \\
\text { moderation }\end{array}$ \\
\hline
\end{tabular}




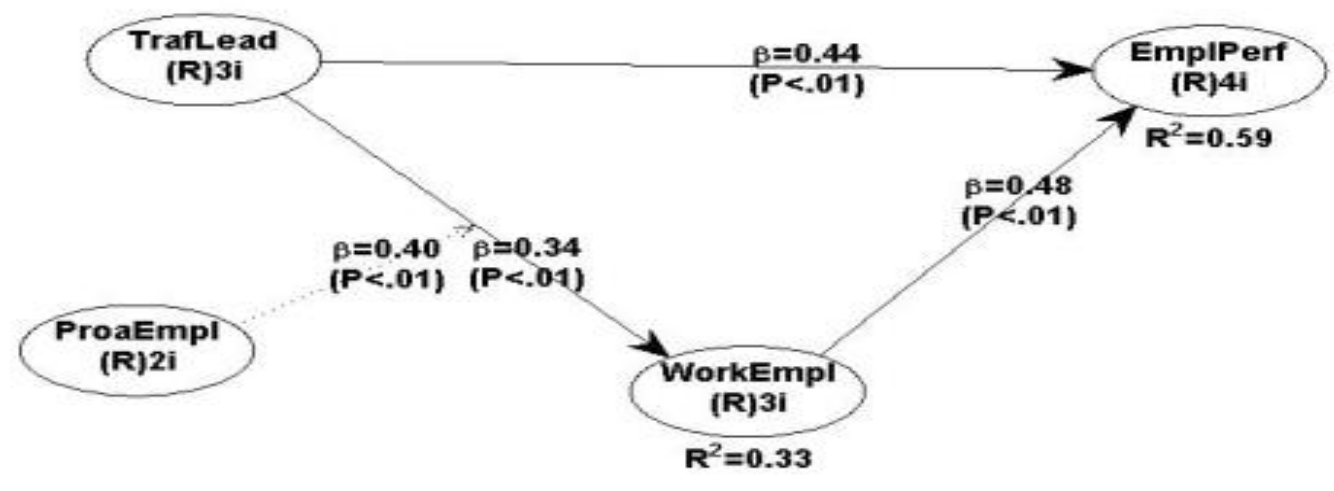

Figure 1. Research result model

\section{DISCUSSION}

Empirical conditions show that the better the transformational leadership, the better the employee's performance at the Bongaya STIEM Campus. There is a strong indication that the dominant transformational leadership displayed by the leader of STIEM Bongaya is leadership with a moon characteristic with a sense of coolness and an impact on employee performance. Leaders with moon characteristics can illuminate the organizational climate when experiencing darkness. A leader like this always provides new enthusiasm, support, and motivation during joy and sorrow, the situation and condition of the leader must be present and act as social glue between employees. The hope is that a harmonious inner atmosphere is always well maintained between leaders and employees or among employees. Employees who feel coolness, harmony, and new enthusiasm will have the motivation to work so that employee performance can be better.

Transformational leadership with the moon character is a self-character that displays conscious behavior in expressing harmonized values and expectations (Zhu et al., 2011) the moonlight is a cooling agent for employees so that they produce good quality work. It is reasonable if it stated that leaders who display moonlight behavior obtain social support so that employees are more flexible in making adjustments to work with the organizational climate and the impact on employee performance to be good (Lee et al., 2013).

The following leadership with a moon character other characteristics of transformational leadership behavior, such as leadership always gives new enthusiasm. The new spirit encourages employees to innovate and motivates employees to be more inspirational at work. Because there is a new spirit, employees are always ready to devote themselves to innovation so that the STIEM Campus is at the forefront and trusted by the community. A successful leader is a leader who always encourages employees to make breakthroughs (Afsar et al., 2014). A recent study by (Suifan et al., 2018) stated that transformational leadership positively affects several employee creativity dimensions (Suifan et al., 2018). Employees are often inspired to do productive work. Employees always maintain the reputation of the organization. Psychologically, they place great trust and hope for the organization. This trust and hope arise from the effect of the transformational leadership role that is developing employee skills through motivation, facilitation support, continuous coaching, changes in mindset, and unpretentious 
communication channels (Sousa and Rocha, 2018). So important is the role of transformational leadership, especially leadership with moon characters, which tends to strengthen employee perceptions of the organization's reputation. (Men and Stacks, 2013) reported the evidence that transformational leadership positively affects employees' perceptions of the organization's reputation.

Empirical evidence that employees who have good performance produce the performance that meets job requirements is on time, performs urgent tasks, and never neglects aspects of the job. It has the same views or measurements of employee performance as revealed by (Groen et al., 2017). Employees who produce a good quality of work receive support from the leadership and can be translated and manifested in real work. Employees' ability to have made good's mind is more harmonious, calm, and comfortable. If the leader has a moon character, encourages employees to innovate, and motivates employees to be more inspirational in their work, employee performance will be better and high in quality. This research hypothesis supports the research hypothesis of (Mullen et al., 2017), (Thomas Ng, 2017), (Tse and Chiu, 2014) reported that the better the transformational leadership on the moon character, the better the employee's performance. It means that the better the transformational leadership with the moon character, the better employee's performance.

We believe that the transformational leadership style with the moon character is a characteristic of the leadership style that is always played by the person who leads the STIEM Bongaya Campus and is a differentiator from the leadership style in other organizations, especially the academic world. A person who has the mandate and trust to rule the STIEM Bongaya Campus is an individual who has competent competence with character as the moon character. The first generation of STIEM Bongaya Foundation had put the meaning and symbols of transformational leadership of a moon character, recently, the second generation maintained the integrity of preserved integrity and the symbol of leadership style. The leadership atmosphere that is often transmitted by the Chairperson of the STIEM Bongaya Foundation transformational leadership with a moon character to the leaders and employees with the new spirit, harmony, comfort, and calmness that haven found on other campuses. The inner atmosphere is such as inner enthusiasm, harmony, comfort, and coolness encourages employees to be involved in doing work.

In reality, it showed psychological factors influence employee involvement. Employees and employees involved in the organization increasingly trust and will be higher (Jena et al., 2017). The positive impact is that the employee's performance is getting better and with quality. Employee involvement is to interpret the emotional commitment when they are doing the work. Employees' satisfaction showed happiness, cheerful, and good behavior while doing their job and do not consider it a burden (Sumail, 2019). It means that employees feel satisfied at work, and the job is not a burden.

(Buil et al., 2018) explained that employee characteristics of employee involvement have three indicators, enthusiasm, dedication, and absorption (full involvement in work). For employees, dedication is defined as dedication through sacrificial actions in the form of energy, thoughts, and time, so those noble goals are achieved. Employees who have dedicated behavior always display the spirit of continuing to work and producing the best work.

High commitment also contributes to reflecting on employee engagement. Commitment to work is a sign that the employee has the morale to be involved in the work. 
The moral is the key to success. A leader with a moon character always radiates calm work so that employee morale is high. Furthermore, we also found that full involvement in the work by employees is quite good. It is a reflection of employee involvement in the work. The study of (Buil et al., 2018) stated that the better transformational leadership, the higher the employee involvement.

Not only does the transformational leadership factor with moon character affect employee engagement attitudes, but it is also determined by individual proactivity. We found that the excessive proactive role of the individual can discourage some employees from engaging at work.

Not only does the transformational leadership factor with moon character affect employee engagement attitudes, but it is also determined by individual proactivity. We found that the excessive proactive role of the individual can discourage some employees from engaging at work. Although transformational leadership with a moon character is always calm, and it found out some individual attitudes tended to show excessive proactive behavior, it was certain to reduce the intention of employee involvement. Excessive individual proactiveness can be caused by changes in the work environment so that it has an impact on reducing work involvement. Studies (Bateman and Crant, 1993) state that proactive behavior as an individual depends on the work environment. On the other hand, we believe that the interaction between transformational leadership with a moony character and a moderate proactive individual will increase employee engagement attitudes. We believe that employees who like to find better ways of doing work can produce a good performance.

(Buil et al., 2018) stated that employees who are characterized by being proactive at work are superior employees who can identify opportunities. Proactive employees are employees of high quality and performance. The demands of market needs or stakeholders are increasingly diverse and urgent. It is necessary to work innovation in taking advantage of opportunities (Afsar et al., 2015). The ability to take advantage of opportunities as a form of creativity through work innovation. When employees serve student needs in a fast and precise way so that served the students feel well. Furthermore, employees who display proactive behavior are reflected in excellence in identifying opportunities. No matter how small the opportunity is, it is always filled with real and productive work.

The tendency of proactive employees in working is high, and it strengthens the attitude of employee involvement in work.

The goal is to improve employee performance. (Presbytero, 2015); (Setti et al., 2015) found that proactive individuals can encourage employee engagement so that employee performance is good and quality.

Often, employee engagement is determined by emotional factors. A concrete example of the role of emotions shown in research (Ouweneel et al., 2012; Yoo and Jeong, 2017; Yulita et al., 2017) explained that employees who characterize work engagement are employees with strong feelings of work commitment and dedication. The previous research by (Paek et al., 2015) stated that employee involvement is influenced by psychological factors, job satisfaction, and organizational commitment. It means that the higher the psychological (emotional) factors, job satisfaction, and organizational commitment, the higher the employee's involvement in doing the job so that the employee's performance is getting better and of quality. 
Transformational leadership with a moon character is shining its light on employees and the employees are more involved in the organization based on their needs, values, and interests (Bosmans et al., 2019). For employees, a necessity of life and has social and economic value interpret to have the interest of doing work.

High dedication, morale, and employee involvement in work shreds of evidence and encourage performance.

(Groen et al., 2017) formulate that employee performance indicators are doing urgent tasks, meeting job requirements, being on time, and never neglecting job aspects. Performance output at STIEM Bongaya must meet job requirements. To have job requirements, employees always have to be heavily involved in work. On the other hand, employee performance is shown by doing urgent work to produce productive, and quality works. Psychologically, employee engagement is infused with emotional energy, a feeling of joy, achievement, and enthusiasm that encourages employees to do urgent work on time and never neglects any aspect of the job. This study found that the higher the involvement, the better the employee's performance. There are similarities with the findings of (Anitha's, 2014); (Gupta, 2019); (Hanaysha, 2016) reports that the higher the involvement, the better the employee's performance.

We found that employee engagement was determined by transformational leadership that had a moon character and had an impact on employee performance.

Transformational leadership with a moon character will encourage employees to be involved in the organization. The employees will interpret work as not a burden but the worship to do work so that employee performance is a good quality of work. (Ghadi et al., 2013) tried to investigate the direct relationship between transformational leadership and job involvement mediated by employees' perceptions of the meaning in work is a positive relationship. Dedication, morale, and full involvement in work are the characteristics of employee involvement, which is to show creative behavior. This creativity arises because of psychological factors where the organization guarantees a good or calm work climate (Yoo and Jeong, 2017). We find evidence that the better the transformational leadership of the moon, the higher the employee engagement. Furthermore, this study also supports the hypothesis proposed by (Anitha, 2014), (Gupta, 2019), (Hanaysha, 2016) that the higher the employee involvement, the higher the employee's performance.

\section{CONCLUSION}

The leader of the STIEM Bongaya campus uses a transformational leadership style with a moon character. It is a differentiator from other organizational leadership styles, especially in the academic world. Currently, the second generation is headed by the STIEM Bongaya Foundation.

The chairman of the STIEM Bongaya Foundation often transmits an atmosphere of leadership with a moon character to the leaders and employees which means a new spirit, harmony, and calmness that has not been found in other campuses in Makassar.

The inner atmosphere is new enthusiasm, harmony, comfort, and calmness encourages employees to be involved in doing work, be proactive, and employee performance.

The radiance of transformational leadership moon character becomes positive energy that can generate emotional commitment by employees. The role of employee involvement is very significant in doing work which is reflected by behaviors such as 
commitment, dedication, and full involvement in work so that employee performance becomes good and qualified. It has taken root in employees that work orientation is noble. Some employees display excessively proactive behavior that discourages engagement intentions by some employees. However, in general, employee involvement tends to be strong because there is a significant proactive role of employees at work. It turns out that a proactive employee is a superior employee and can seize opportunities assuming a proactive attitude is not excessive. The ability to take advantage of opportunities as a form of creativity through work innovation. Therefore, the tendency of proactive employees at work is higher, and it strengthens the employee involvement in work. The end is that employee performance increases.

In obtaining quality information accuracy, alumni future research can be used as a unit of analysis or samples.

\section{REFERENCES}

Afsar, B., Badir, Y., and Muddassar, M. (2015). Person - job fit, person organization fit and innovative work behavior: The mediating role of innovation trust. Journal of High Technology Management Research, 26(2), 105-116.

Afsar, B., Badir, Y., and Saeed, B. (2014). Transformational leadership and innovative work behavior. Industrial Management and Data Systems, 114(8), 1270-1300.

Afsar, B., and Umrani, W. A. (2019). Transformational leadership and innovative work behavior: The role of motivation to learn, task complexity and innovation climate. European Journal of Innovation Management, xxx(xxx)xxx-xxx.

Al-edenat, M. (2018). Reinforcing innovation through transformational leadership: mediating role of job satisfaction. Journal of Organizational Change Management, 31(4), 810-838.

Anitha. (2014). Determinants of employee engagement and their impact on employee performance. International Journal of Productivity and Performance Management, 63(3), 308-323.

Antonakis, J., and House, R. J. (2014). Instrumental leadership: Measurement and extension of transformational-transactional leadership theory. Leadership Quarterly, 25(4), 746-771.

Bateman, T. S., and Crant, J. M. (1993). The proactive component of organizational behavior: A measure and correlates. Journal of Organizational Behavior, 14(2), $103-118$.

Bass, B.M. (1985). Leadership and Performance Beyond Expectations. New York: The Free Press.

Bosmans, M. W. G., Setti, I., Sommovigo, V., and van der Velden, P. G. (2019). Do Type $\mathrm{D}$ personality and job demands-resources predict emotional exhaustion and work engagement? A 3-wave prospective study. Personality and Individual Differences, 149(January), 167-173.

Buil, I., Martínez, E., and Matute, J. (2018). Transformational leadership and employee performance: The role of identification, engagement and proactive personality. International Journal of Hospitality Management, $x x x(\mathrm{xxx}), \mathrm{xxx}-\mathrm{xxx}$. 
Ding, X., Li, Q., Zhang, H., Sheng, Z., and Wang, Z. (2017). Linking transformational leadership and work outcomes in temporary organizations: A social identity approach. International Journal of Project Management, 35(4), 543-556.

Ghadi, M. Y., Fernando, M., and Caputi, P. (2013). Transformational leadership and work engagement: The mediating effect of meaning in work. Leadership and Organization Development Journal, 34(6), 532-550.

Groen, B. a. C., Wouters, M. J. F., and Wilderom, C. P. M. (2017). Employee participation, performance metrics, and job performance: A survey study based on selfdetermination theory. Management Accounting Research, 36, 51-66.

Gumusluoglu, L., and Ilsev, A. (2009). Transformational leadership, creativity, and organizational innovation. Journal of Business Research, 62(4), 461-473.

Gupta, M. (2019). Does work engagement mediate the perceived career support- and career adaptability- work performance relationship? Journal of Global Operations and Strategic Sourcing, 12(2), 310-327.

Hanaysha, J. (2016). Testing the Effects of Employee Engagement, Work Environment, and Organizational Learning on Organizational Commitment. Procedia - Social and Behavioral Sciences, 229, 289-297.

Jena, L. K., Pradhan, S., and Panigrahy, N. P. (2017). Pursuit of organisational trust: Role of employee engagement, psychological well-being and transformational leadership. Asia Pacific Management Review, xxx(xxx), 1-8.

Kara, D., Uysal, M., Sirgy, M. J., and Lee, G. (2013). The effects of leadership style on employee well-being in hospitality. International Journal of Hospitality Management, 34(1), 9-18.

Lee, L. Y., Veasna, S., and Wu, W. Y. (2013). The effects of social support and transformational leadership on expatriate adjustment and performance: The moderating roles of socialization experience and cultural intelligence. Career Development International, 18(4), 377-415.

Li, C., Zhao, H., and Begley, T. M. (2015). Transformational leadership dimensions and employee creativity in China: A cross-level analysis. Journal of Business Research, 68(6), 1149-1156.

Li, X., Sanders, K., and Frenkel, S. (2012). How leader-member exchange, work engagement and HRM consistency explain Chinese luxury hotel employees' job performance. International Journal of Hospitality Management, 31(4), 1059-1066.

Li, Y., Castaño, G., and Li, Y. (2018). Linking leadership styles to work engagement: The role of psychological capital among Chinese knowledge workers. Chinese Management Studies, 12(2), 433-452.

Mahmood, M., Uddin, M. A., and Fan, L. (2019). The influence of transformational leadership on employees' creative process engagement: A multi-level analysis. Management Decision, 57(3), 741-764.

Men, L. R., and Stacks, D. W. (2013). The impact of leadership style and employee empowerment on perceived organizational reputation. Journal of Communication Management, 17(2), 171-192.

Mohamad Taha Arif. (1986). Book Review: Leadership and Performance Beyond Expectations, by Bernard M. Bass. Human Resource Managemen (Vol. 25). 
Monje Amor, A., Abeal Vázquez, J. P., and Faíña, J. A. (2019). Transformational leadership and work engagement: Exploring the mediating role of structural empowerment. European Management Journal, xxx(xxx)xxx-xxx.

Mullen, J., Kelloway, E. K., and Teed, M. (2017). Employer safety obligations, transformational leadership and their interactive effects on employee safety performance. Safety Science, 91, 405-412.

Ouweneel, E., Le Blanc, P. M., and Schaufeli, W. B. (2012). Don't leave your heart at home: Gain cycles of positive emotions, resources, and engagement at work. Career Development International, 17(6), 537-556.

Paek, S., Schuckert, M., Terry, T., and Lee, G. (2015). International Journal of Hospitality Management Why is hospitality employees' psychological capital important? The effects of psychological capital on work engagement and employee morale. International Journal of Hospitality Management, 50, 9-26.

Presbitero, A. (2015). Proactivity in career development of employees: The roles of proactive personality and cognitive complexity. Career Development International, 20(5), 525-538.

Rönnblom, M., and Keisu, B. I. (2013). Constructions of innovation and gender (equality) in Swedish universities. International Journal of Gender and Entrepreneurship, 5(3), 342-356.

Rowe, A. M. (2018). Gender and innovation policy in Canada and Sweden. International Journal of Gender and Entrepreneurship, 10(4), 344-360.

Setti, I., Dordoni, P., Piccoli, B., Bellotto, M., and Argentero, P. (2015). Proactive personality and training motivation among older workers A mediational model of goal orientation. European Journal of Training and Development, 39(8), 681-699.

Sharma, P. N., and Pearsall, M. J. (2016). Leading Under Adversity: Interactive Effects of Acute Stressors and Upper-Level Supportive Leadership Climate on Lower-Level Supportive Leadership Climate. Leadership Quarterly, 27(6), 856-868.

Solimun., Adji A. R., dan Nurjannah. (2017). Metode Statistika Multivariat: pemodelan Persamaan Struktural (SEM) Pendekatan WarpPLS. UB Press Malang.

Sousa, M. J., and Rocha, Á. (2018). Leadership styles and skills developed through gamebased learning. Journal of Business Research, (August 2017), 0-1.

Suifan, T. S., Abdallah, A. B., and Al Janini, M. (2018). The impact of transformational leadership on employees' creativity: The mediating role of perceived organizational support. Management Research Review, 41(1), 113-132.

Sumail, L. O. (2019). The effect of job demand on the work engagement: Does supervisory support matter in the Indonesian financial service sector. International Journal of Innovation, Creativity and Change, 6(8), 192-210.

Sumail, L. O., and Abdullah, S. (2019). Innovative Behavior And Emotional Intelligence Of Managers In Managing A Catering Business. Jurnal Manajemen, 23(2), 290.

Thomas Ng, W. H. (2017). Transformational leadership and performance outcomes: Analyses of multiple mediation pathways. Leadership Quarterly, 28(3), 385-417.

Tims, M., Bakker, A. B., and Xanthopoulou, D. (2011). Do transformational leaders enhance their followers' daily work engagement? Leadership Quarterly, 22(1), 121131. 
Tse, H. H. M., and Chiu, W. C. K. (2014). Transformational leadership and job performance: A social identity perspective. Journal of Business Research, 67(1), $2827-2835$.

Wang, Z., Zhang, J., Thomas, C. L., Yu, J., and Spitzmueller, C. (2017). Explaining benefits of employee proactive personality: The role of engagement, team proactivity composition and perceived organizational support. Journal of Vocational Behavior, 101(April), 90-103.

Yang, K., Yan, X., Fan, J., and Luo, Z. (2017). Leader-follower congruence in proactive personality and work engagement: A polynomial regression analysis. Personality and Individual Differences, 105, 43-46.

Yao, Y.-H., Fan, Y.-Y., Guo, Y.-X., and Li, Y. (2014). Leadership, work stress and employee behavior. Chinese Management Studies, 8(1), 109-126.

Yoo, J., and Jeong, J. (2017). The effects of emotional labor on work engagement and boundary spanner creativity. Asia Pacific Journal of Innovation and Entrepreneurship, 11(2), 214-232.

Yulita, Dollard, M. F., and Idris, M. A. (2017). Climate congruence: How espoused psychosocial safety climate and enacted managerial support affect emotional exhaustion and work engagement. Safety Science, 96, 132-142.

Zhu, W., Avolio, B. J., Riggio, R. E., and Sosik, J. J. (2011). The effect of authentic transformational leadership on follower and group ethics. Leadership Quarterly, 22(5), 801-817. 